Journal of Humanities and Social Sciences Studies (JHSSS)

ISSN: 2663-7197

DOI: $10.32996 /$ jhsss

Journal Homepage: www.al-kindipublisher.com/index.php/jhsss

\title{
The Moroccan Nationalist Movement and its Anticolonial Activism from 1925 to 1944
}

\author{
Abdellatif El Aidi 8 (D) \\ Assistant Professor, Research Laboratory: Discourse, Creativity, Society and Religions Faculty of Arts Saiss-Fez, Sidi Mohamed Ben \\ Abdellah University, Fez, Morocco
}

Corresponding Author: Abdellatif El Aidi, E-mail: elaidiii2014@gmail.com

\section{ARTICLE INFORMATION \\ Received: August 04, 2021 \\ Accepted: September 20, 2021 \\ Volume: 3 \\ Issue: 9 \\ DOI: $10.32996 /$ jhsss.2021.3.9.4}

\section{KEYWORDS}

France, independence, Morocco, nationalist movement, protectorate, reforms, Spain.

\section{ABSTRACT}

During the latter part of the Nineteenth Century, the European colonial rivalry over Morocco intensified. The European powers targeted the North African country because of its strategic location and rich natural resources. Hence, after establishing the French and Spanish Protectorates over Morocco, the colonial powers started to implement their exploitative policies in the Sherifian Kingdom. Those policies provoked the Moroccan people, who refused any foreign presence in their country and pushed them to engage in armed resistance. However, the failure of the armed resistance to liberate Morocco and the emergence of a new generation saturated with the spirit of peaceful resistance contributed to the birth of the Moroccan nationalist movement as a political organization aiming to confront the colonizers' plans and ambitions by peaceful means. The present paper is intended to highlight the political struggle of the Moroccan nationalist movement from its inception to 1944. More specifically, the paper aims to outline the factors contributing to the emergence of the movement and the means of actions it adopted in its peaceful struggle against colonialism. Finllay, it discusses the historical events that encouraged the nationalist movement to move from calling for reforms to calling for full independence.

\section{Introduction}

It was not a coincidence that Morocco became the focus of ambitions of the European colonial powers since the early nineteenth century. Indeed, the country benefits from a good strategic geographic location and is characterized by abundant natural resources. The evidence that the colonization of Morocco was carried out on the basis of a preplanned agenda is those bilateral agreements and arrangements between the European colonial powers, which culminated in the establishment of the French and Spanish Protectorates over Morocco in 1912. Hence, Morocco became divided into French and Spanish spheres of influence by consensus at an international level. Despite all the pledges made in the Protectorate Agreement, Morocco became a colony state without sovereignty. However, the Moroccan people did not accept these colonial conspiracies weaved against their country, thus escalating the armed struggle for independence. Nevertheless, after the defeat of the armed resistance, the Moroccan people had to think about other ways to confront the colonial powers. Hence, an educated elite realized that it was time to face the colonizer by peaceful means. Therefore, the nationalist movement was formed. The purpose of this paper is to explore the non-violent struggle which the movement led against colonialism.

\section{The Establishment of the Moroccan Nationalist Movement}

The Moroccan nationalist movement was established in November 1925, gathering a group of educated young people to examine how the relationship between Morocco and France's Protectorate administration could be reformed. (Halstead, 1967, p. 166) These educated young people met many times a week to discuss and comment on Arabic and French newspapers and books from other countries. (Wyrtzen, 2015, p. 140) In this regard, due to the defeat of the armed resistance in the Moroccan Rif and the surrender of its leader Mohamed Ben Abdelkrim El Khattabi in 1926, the young educated people of the cities began to

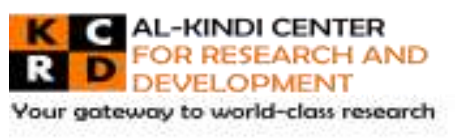

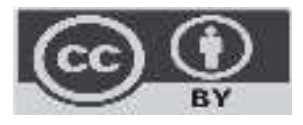

Published by Al-Kindi Center for Research and Development. Copyright (c) the author(s). This open access article is distributed under a Creative Commons Attribution (CC-BY) 4.0 license 
feel hopeless and disappointed. This state of despair prompted them to give up the armed struggle for the sake of political action.

After the retirement of the French Resident General Lyautey, which made Moroccans lose hope in the application of selfgovernment, the Moroccan nationalist movement witnessed a political revival through the activities of these young educated Moroccans. According to Suliman, there were two major trends among Young Moroccans. The first was a traditional religious trend inspired by the Salafi movement that emerged in the 19th century from the teachings of Jamal al-din al-Afghani and Mohamed Abduh. The other trend was a political movement stemming from the modern European culture which came through the educational system established by the French in Morocco. (1987, p. 28) Led by 'Allal al-Fassi, the Islamic reformist movement insisted on getting back to the pure religion which was practised by the first Muslim generations. The followers of the religious movement called for developing a modernized system of Islamic law, revitalizing the Arabic language, and purifying heretical expressions of Islam in the country's widespread Sufi brotherhoods, or zawiyas. (Wyrtzen, 2015, p.140) On the other hand, the political movement, led by Ahmed Balafrej, was interested in modern culture. However, despite the profound ideological and cultural differences separating the two trends, they united in one group by common patriotic sentiments in 1927 while the occasion for their common national action came three years later. (Sulima, 1987, p. 28)

Another contributing factor to the emergence of the Moroccan nationalist movement is the Great Depression. In fact, despite the growth in the Moroccan economy from 1912 until the beginning of the Great Depression of 1930 and despite the increase in Foreign trade from 170 million francs in 1912 to more than three and three quarters of a billion francs in 1929, this economic expansion was in favor of the French residents. While the latter enjoyed significant economic benefits, the living conditions of the natives deteriorated. They suffered from excessive taxation, a decline of the crafts, commercial instability, lack of employment for the educated, rising cost-of-living, and monetary depreciation. (Kenneth, 1973, p. 203) These deteriorating economic conditions affected the young urban residents and increased their resentment against the French.

However, the promulgation of the Berber Dahir remains the most important factor contributing to the emergence of the Moroccan nationalist movement. On 16 May 1930, the French residency in Rabat issued the famous Berber Dahir, which codified a distinct judicial system based on tribal customs in Berber regions, thus setting them apart from the predominantly Arab regions which were subject to the jurisdiction of Sharia law. (Stenner, 2016, p. 436) The young educated Moroccans considered the religion of Islam, the Arabic language and culture as cultural identity markers, without which the unity of Morocco could not be achieved. Therefore, the issuance of the Berber Dahir unleashed the first public demonstration against the protectorate, giving voice to Moroccan proto-nationalism. (De Poli, 2016, P. 32) Therefore, in conformity with the Moroccan culture, the rejection of the so-called Berber Dahir was expressed in religious terms. For example, to energize protests against the French, the nationalists resorted to the traditional latif prayer in mosques, adding to it the statement "and do not separate us from our brothers, the Berbers." (Wyrtzen, 2011, p. 232) Although the protest started in Rabat and Salé, the latif profoundly affected all Moroccans, who massively demonstrated in the major cities until September. In an attempt to support and organize the massive protests, the promoters of the latif in Fes ('Allāl al-Fāsī, Ḥasan al-Wazzānī, Aḥmad Makwār, Ḥasan Bū'ayyād, 'Abd al-Qādir al-Tāzī and Muhammad al-Dyūrī) founded the Jamā'a al-wațaniyya (Patriotic Group) to defend 'religion, fatherland and throne. The French response to these protests was violent, as they launched a campaign of repression and arrests against the protesters, which prompted the patriotic group to move outside the borders of Morocco. (De Poli, 2016, p. 32)

\section{Chakib Arslan and the Internationalization of the Moroccan Cause}

From its very foundation, the Moroccan nationalist movement had displayed an internationalist perspective on politics. As Halstead (1967) points out, many members of the Istiqlal's future leaders had gone to Egypt, where they joined the Westernstyle Fuad University or the Islamic al-Azhar University and became acquainted with the major intellectual trends of the Middle East. (As cited in Stenner, 2012, p. 4) Besides, because of creating a modern educational system for the sons of the native elites, the first group of young Moroccans travelled to Metropolitan France to continue their university studies. There the young Moroccan students made contact with their Algerian and Tunisian peers. In 1927, the North African students created the Association des Étudiants Musulmans Nord-Africains (The North African Muslim Students Association) to supply assistance and help for North Africans living in France. (Berkaoui, 2003, p. 102) This association, as Ageron (1983) makes the point, became a clearinghouse for nationalist ideas, where the Moroccan students met students from all the countries of the Margheb, as well as militants from the labour-unionbacked Tunisian Neo-Destour and Algerian Messali Hajj's proletarian Etoile Nord-Africaine (North African Star). (As cited in Stenner, 2012, p. 4)

However, the most prominent event that greatly affected the path of the Moroccan nationalist movement was the meeting of the Moroccan students in Paris with the eminent Lebanese nationalist Shakib Arslan. The Prince of eloquence (amir al-bayan) offered much advice to the future leaders of the Moroccan nationalist movement. It was he who introduced them to the ABCs of 
modern politics. In a letter instructing the amir about the students' latest political activities, Balafrej wrote, 'I am ready to do any service that you order me to do.' (Stenner, 2016, p. 435) In addition to the counselling services he provided for the young Moroccans, Arsalan enabled them to make their voice heard to the world through his networks of newspapers and journals.

In the summer of 1930, Balafrej and al-Fassi went with Arslan on tour to Spain, then arranged for him a ten-day visit to Tangier and Tetouan from August 9-19th, at the peak of the Latif protests in the French region. (Cleveland, 1985, 90-114) During his stay in Tetouan, he gathered with the representatives of the nationalist groups of Fes and Rabat Ahmad Balāfrīj, 'Umar 'Abd al-Jalīl and Muhammad al-Fāsī, whom he advised never to act or talk in a way that could allude to the idea of Jihad (war for faith). On the contrary, he encouraged them to uncover in their anticolonial struggle the French violation of the civil rights set forth in the treaty of Fes.(Ibn Azzouz Hakim, 1980, p. 16)

After leaving Tetouan, Arslan went back to Geneva and launched a harsh attack on the policy of divide and rule which the French adopted in Morocco. He used his French-language journal La Nation Arabe to criticize the French colonial expansion in the countries of North Africa. For example, in an article entitled "Tribunaux Berbères," appeared in the August/September 1930 volume of the mentioned journal, Arslan lashed out at the Resident General, Lucien "Saint:" "Mr. Saint must justify his name and figure in this century for having achieved the work of Ferdinand and Isabella. They converted the Moors in Spain, and will he not convert the Moors in Africa?" (As cited in Wyrtzen, 2009, p. 161) He also published several articles about the Berber Dahir in Cairo's major Arabic periodicals, such as al Manar, al Fath and al Zahra. Once introduced by the amir, the Moroccan cause was touched upon by newspapersin Tunis, Tripoli, Beirut, Jaffa, and Damascus, editorialists demonized France as an "enemy of Islam." (Wyrtzen, 2015, p. 149)

Thanks to this coverage of the Berber issue in the Arabic language, sympathy for the Moroccan cause increased in the Arab world. The best example to illustrate this sympathy is the Libyan Imam Bashir Ben El Hamza, who in October 1930 benefited from the Italian indulgence towards the anti-French controversy, to castigate France's divisive policy in Morocco and to incite people to rally against this policy. Besides, Arabic newspapers such as Al-Raqib, Al-Atid, and Al-Adel started for the first time in the fall of 1930 to cover the plight of the Moroccan Berbers regarding it as a menace to the religion of Islam and the Muslim community as a whole. The same protests against the Berber Dahir spread in Cairo, where the Universal Association of Muslim Youth planned a demonstration in front of the French consulate to demand the repeal of the infamous decree. Similarly, twelve Muslim associations gathered in Java to establish the Muslim Committee for the Defense of Berbers. (Wyrtzen, 2009, p. 162)

Indeed, the young Moroccan's contact with Arslan positively affected their struggle against the French protectorate. He not only taught them the importance of making their cause internationally known, but also provided them with the tools to achieve that goal. Besides, because he had already spent more than a decade securing support within the League of Nations for Syria's and Palestine's independence from France and Britain, the man became an expert in defending the colonized peoples. Therefore, when he involved himself in the Moroccan crisis, he gave the Moroccan struggle a kind of legitimacy in the Middle East. Therefore, with his death in 1946, Moroccans lost a major player in their international network. (Stenner, 2012, p. 5)

To fill the void in keeping the world informed about the Moroccan crisis left by the death of Arslan, the nationalists decided to get in touch with the French and Middle Eastern peoples on their own. Therefore, a few months after the death of their staunch advocate, they created the 'Office of the Arab Maghrib' in Cairo under the command of the Istiqlali leader 'Allal al-Fassi' in 1947. At that time, the Egyptian capital became the most important place embracing the elements of the Moroccan nationalist movement: "with the founding of the Arab League in 1945 and the rise of Nasser as the leader of the pan-Arab movement in the 1950s, Cairo transcended Paris as a base for expatriate Moroccan nationalist activity." (Wyrtzen, 2015, p. 150)

\section{The Means of Action Adopted by the Moroccan Nationalist Movement}

The means of action which the Moroccan nationalist movement relied on in its struggle against colonialism can be summed up as follows: Edudation, press and media, political parties.

\subsection{Education Reform}

The educational system established by France and Spain during their colonization of Morocco was not intended to bring Moroccans out of the darkness of ignorance into the light of knowledge. On the contrary, education was viewed as a complementary weapon to military control. It was used to indoctrinate the natives with a set of colonialist ideologies to win over their minds. For example, the young Moroccans who attended French schools were brainwashed into thinking French culture is superior to Moroccan culture. They yearned to leave 'the patriarchal tyranny' of Islam and join the free life of the French capital. (Cline, 1947, p. 22) Therefore, the main goal behind the establishment of French schools in the colonized Morocco was to erase 
its people's Arab and Islamic identity. This was evident from the educational programs taught in those schools, which focused mainly on teaching the language and history of France, as well as the Christian religion.

Racist as it was, the colonial educational system was not available for all Moroccans. The colonial powers devoted most of their new schools for the sons of the elite: "The écoles des fils de notableswere primary schools that fed into even more restricted secondary schools like the Collèges Musulmans in Fez (founded in 1914)and Rabat (1916). Their purpose was to produce a loyal class of young bureaucrats." (Pennell, 2003, p. 150) Therfore, the education system established under the French protectorate was used as a tool to divide Moroccans. This was obvious from the creation of the Berber school system stipulated in the Berber Dahir. "Schools such as the Lycée Moulay Ismail in Meknes and the Lycée Franco-Berber in Azrou all taught French as the first language and Berber as a second." (Bahij, 2013, p. 129). These Franco-Berber schools, in which the cultural identity markers (language, history, religion... etc) of Morocco are completely ignored, was conclusive evidence that education was part of the French 'divide and rule' policy.

Realizing the danger of the French educational system, the nationalists attached high priority to reforming the education sector. Combating illiteracy, expanding education to include the largest proportion of the population, constructing modern Morroccanized schools and defending the Arabic language, Moroccan history and the Islamic religion became important goals that the Moroccan nationalist movement sought to achieve. (González González, 2015, p. 276) In the beginning, the nationalists decided to boycott the schools of the colonisers, preferring to send their children to the old msi'ds (local Qur'anic schools). They then started to think of reforming the Qarawiyyin and founded free schools. (Ait Mous, 2013, p. 744) These schools were called free schools because they were independent of French supervision and control. The first free school was built in 1921 in Fes and its purpose was to provide modern Islamic education in Arabic. (Pennell, 2003, p. 150) Therefore, education reform was the first tool the nationalist movement adopted to confront colonialism and its plans aiming to divide Morocco.

\section{2. The Press and Media}

In addition to education, the nationalist movement also used the press and media to publicize their demands and to uncover the crimes and brutalities committed by the colonial powers in Morocco. Indeed the establishment of a press culture in Morocco started with the issuance of a French decree on 27 April, 1914. Although the decree announced the codification of the press and media in Morocco, it gave priority to the French press. (Tayebi, 2013, p. 499) Thus, it is not surprising that Havas, a famous Parisian printing house, was the first to appear in Morocco, which contributed to the emergence of many journals and newspapers. Indeed, even the newspapers that had existed before the emergence of Havas in Morocco, such as La Presse Marocaine, Le Progrès Marocain and L' Echo du Maroc, joined the French printing house. The latter was subject to strict control by the occupation forces that determined what could be published and what could not. In this way, France wanted to control the minds of Moroccans by spreading the ideas that would serve its imperialist project in the Sherifian kingdom. Despite the French strict censorship, some newspapers, such as L'Echo du Maroc, dared to attack the French and their expansionist policies. (Tayebi, 2013, p. 500)

\begin{tabular}{|c|c|c|}
\hline Title & Place of Appearance & Date of Appearance \\
\hline L'Echo du Bled & Casablanca & March 1926 \\
\hline L'Etre Française & Casablanca & May 1926 \\
\hline Le Travail & Oujda & Juin 1926 \\
\hline La Bougie de Fez & Fez & September 1926 \\
\hline L'Echo de France & Casablanca & October 1926 \\
\hline Les Annales Marocaines & Casablanca & 1926 \\
\hline Le Cri de Maàrif & Casablanca & 1926 \\
\hline La Voix du Sud & Marrakech & 1926 \\
\hline Le Réveil du Moghreb & Marrakech & 1926 \\
\hline La Vie Casablancaise & Casablanca & January 1927 \\
\hline Les Potins du Maroc & Rabat & March 1927 \\
\hline Redd-Balek & Casablanca & July 1927 \\
\hline L'Antenne Marocaine & Casablanca & November 1927 \\
\hline
\end{tabular}




\begin{tabular}{|c|c|c|}
\hline La Vérité Marocaine & Rabat & 1927 \\
\hline L'Avenir de Fez & Fez & January 1928 \\
\hline Casa qui Ri & Casablanca & September 1928 \\
\hline Radio Phare & Casablanca & October 1928 \\
\hline
\end{tabular}

Newspapers edited in French under the reign of Théodore Steeg (Tayebi, 2013, p. 500)

It is clear from the number of newspapers published in French that France was keen to impose the French language and culture on Moroccans. However, with the emergence of the nationalist movement, many newspapers edited in Arabic started to see the light. The nationalists wanted to uncover the reality of the colonizer in Arabic so that their ideas would reach all Moroccans. And because of the harassment that the newspapers edited in Arabic were suffering from at the hands of the French, who shut down many of them, the nationalists began to publish these newspapers secretly. Among these secret newspapers, one can mention "Al Islah," which played an essential role in educating Moroccans about the danger of colonialism. (Tayebi, 2013, p. 501) It is important to note that the Moroccan nationalists who received a French education like Abdellatif Sbihi, Mohammed Hassan ElOuazzani and many others contributed to the emergence of a nationalistic press edited in the language of the colonizer. For example, El-Ouazzani was one of the principal collaborators of Maghreb and of l'Action du Peuple. (Tayebi, 2013, p. 501) In brief, the press and media were used by the nationalist movement as an anti-colonial tool to express their refusal of the French presence in Morocco and to sensitize Moroccans to its dangers.

\subsection{Establishing Political Parties}

While preparing to protest against the Berber Dahir, it is said that the young protesters of Sale did not agree on the nature of ideas to be used to mobilize people. There were two different views. The first proposed to approach the decree from a political point of view by insisting on the damage the colonial administration did to the homeland. The other, apparently dominant, opted for religious resistance because the latter was stronger among Moroccans than nationalist sentiment. (Rachik et al., 2007) This disagreement was the result of the dual orientation of the young Moroccans. The latter was divided into two categories. While the first category studied in French schools, the second remained imprisoned in the Arab culture. Therefore, it is no surprise that there were two centers of action during the Latif protest. One of them was headed by a traditionalist leader, 'Allal al-Fassi, Mohammed el Ouazzani led the other. The first founded the national party (el hizb el ouatani) and the second the popular movement (el haraka el qoumiya). (Montagne, 1937, p. 453) Despite the clear difference in belief between the two parties, they agreed to defend the homeland against the colonialists.

However, the two organizations had little effect on Moroccan people because they were clandestine organizations. The first overtly nationalist party in Morocco was Kutlat al-'Amal al- Watani (National Action Bloc or Comite' d'Action Marocaine in French). This party was officially established in May 1934. It contained between 200 and 300 members that year. (Damis, 1970, p. 80) Among its leaders at that time were the eloquent Allal al-Fasi, Ahmad Mikwar, Ahmad Balafraj, Si Muhammad Laghzawi, Si Muhammad al-Fasi and Umar ibn Abd al-Jalil. Despite the tremendous efforts made by these leaders, only 3000 people from the French Morocco joined the National Action Bloc. Most of them were young men from Fez, Tetuan, and Rabat. Not only did the nationalists in the Spanish zone support the National Action Bloc, but also established two organizations of their own. The first, which was led by Abd al-Khaliq al-Turrays, was called the "National Reform Party" (Hizb al-Islah al- Watani) and the second under the leadership of Al-Makki al-Nasiri was named the "Moroccan Unity Movement" (Harakat al-Waahdah al-Maghribiyah). These two organizations united during World War II. (Celine, 1947, pp. 23-4) In December 1943, dozens of young people gathered in Rabat and established Hizb al-Istiqlal (Independence Party) under the leadership of Allal al-Fasi, which quickly became the largest political party in Morocco. (Stenner, 2019, p. 4) These political parties played an essential role in the independence of Morocco by mobilizing Moroccans to revolt against the colonialists, issuing anti-colonialist journals and newspapers, building national schools etc.

\section{Kutlat al-'Amal al- Watani and the Plan of Moroccan Reforms}

After the establishment of Kutlat al-'Amal al- Watani (Comité d'Action Marocaine) in 1934, its members drafted a lengthy plan of reforms and submitted it to the French authorities. The plan of reforms did not call for the complete abrogation of the protectorate. Instead, it demanded the rigorous application of what was agreed upon in the treaty, by which France committed itself to help Morocco build a modern state: "the Plan was essentially a request that France live up to her obligations as the Protectorate Power according to the terms of the Treaty of Fez of 1912. It contained no mention of independence." (Damis, 1970, p. 80) However, although they did not ask for the complete independence of Morocco, the reformists insisted that the Protectorate administration should grant Moroccans the same rights as the French in all areas of social and political life. 
Indeed, the plan of reforms was the product of an arduous shared effort. According to Halstead(1969), Some portions of the document were completely produced by one person and then discussed in a gathering, while other chapters were the result of a collective work. The reports of the gatherings, the first drafts and the last version of the document were all written in Arabic. Before the French edition was printed in Paris in November 1934, the first copy in Arabic had been printed in Cairo in September. The French version was considered the official document and subsequently was handed over to the Sultan and the French government on December 1st. (De Poli, 2016, p. 35)

The reform plan drawn up by the National Action Bloc outlined the demands of the Moroccan people. These demands included political reforms, aiming to protect the national unity and territoritorial integrity of the Sherifian kingdom, preserve the soverignty of the Sultan, establish Arabic as an official language, and maintain Islam as the state religion of Morocco and ensure respect for the Moroccan national flag. Besides, founding a modern state with local and national representative institutions was one of the most important demands the reform plan insisted on. As for the executive authority, the plan called for the establishment of a Moroccan government with ministers having authority over the existing administrative services. The recruitment of civil servants must be ensured by competitive examination, and priority should be given to Moroccans. (Séhimi, 1989, p. 223)

As for the French policy in Morocco, the plan denounced it in the following words: "It is racial [...]; it promotes fiscal and budgetary favouritism [...]; it isobscurantist [...]; anti-liberal [...]; colonialist [...]; assimilationist: it is based on the principleof direct administration and takes the shape of an organised struggle against our institutions,our Arab culture and our traditions." (De Poli, 2016, p. 35) Hence, the plan demanded that an end be put to all kinds of harrassment and arbitrary arrest of Moroccan citizens. It also called for the separation of powers enjoyed by pashas and caids, freedom of the press, freedom to assemble, the unification of the judicial system, the administration reform and the appointment of Moroccans in all its branches, the reform of the education sector, establishing municipal councils and allowing Moroccans to elect them. (Lawrence, 2012, p.477)

Despite the moderate tone of the plan, which did not demand the expulsion of the French authorities from Morocco, but just called for some reforms that would protect Moroccans from the oppression of the French, the latter's response was not only negative, but violent as well. In other words, the French refused the plan in its entirety and decided to banish all the persons whose names were mentioned in the document. The Sultan Muhammad V, who took a positive view of the plan, showed much sympathy for the members of the National Action Bloc. For example, he was prepared to make a public confession of his consent to the plan. To reach a consensus solution, the French Resident decided to backtrack on his intention to deport the plan's designers provided that the Sultan retracts his decision to publically recognize the document. (Damis, 1970, p. 80)

On the other hand, despite its failure to achieve the desired reforms, the plan played a significant role in the development of national sentiment in Moroccans. In this regards, the French residency, which rejected the plan altogether, claimed that the Moroccan people did not express any objection towards its policy, and therefore the document only represents its signatories. This blatant claim prompted the members of the Comité d'Action to think about expanding the popular base of the party. Therefore, when the National Action Bloc held its first congress on October 25, 1936 in Rabat, it decided to organize big rallies all over Morocco with the aim of expanding its popular base. As De Poli makes the point, "the Kutla aimed at establishing a large scale and firm organization, based on the widest possible popular participation, opening new branches. To this end, an Executive Committee, a High Council, technical committees and local sections were set up, launching a recruitment campaign." (2016, p. 36) In a short period of time, these efforts managed to attract thousands of people to join the party. Besides, new branches were established in different parts of the country and were added to the already existing ones.

\section{The Nationalists' Call for Full Independence}

The French rejection of the reform demands made by the Moroccan nationalist movement exacerbated the political situation in Morocco and pushed the nationalists to escalate their demands as they started to call for complete abrogation of the Protectorate. But how did the nationalist movement dare to demand full independence although the colonizer had defeated all kinds of Moroccan armed resistance? Indeed, the protectorate's categorical refusal of the reform plan drawn by the CAM was followed by a set of motivating factors that encouraged the nationalists to shift from calling the French to adjust their policies towards the Moroccan people to an outright demand for their expulsion from Morocco.

The first incentive that drove the nationalists towards demanding the withdrawal of the French from Morocco was the outbreak of the Second World War in 1939. In this regard, most specialists believe that the war shook the colonial system and exposed its weaknesses. The fall of France and its occupation by Hitler shattered the myth of the invincibility of the French occupying army. Despite the fact that the French presence was not really affected by the declaration of war, France's defeat in June 1940 had serious implications throughout its colonies, including Morocco. In other words, "as a great power, France suffered a loss of prestige from her relatively quick capitulation to the Nazi war machine; this was compounded by the Japanese occupation of 
French Indo-China in September and the Lebanese declaration of independence in November of the same year." (Damis, 1970, p. 83)

The sencond incentive was the Atlantic Charter, which the United States of America signed with a group of European imperialist countries in 1941. Through the Atlantic Charter, the American president imposed on the European leaders an essential condition in exchange for his country to enter the war with them. This condition was the right of peoples to self-determination. Therefore, the ethical obligations guranteed by the Allies in the Atlantic charter were exploited by the nationalist movement in order to call for the restoration of the independence and the unity of Morocco as well as the establishment of a democratic constitutional monarchy based on consultation, the same as in the countries of the Islamic Arab East. (Suliman, 1987, p. 31)

The meeting of Anfa in January 1943, which brought together the leaders of the Allied Forces in the city of Casablanca, was another motive for the nationalist movement to demand independence from France. Sultan Mohamed ben Youssef took advantage of Roosevelt's presence in Morocco to gain American support. In this regard, some sources mentioned that "President Roosevelt received Sultan Mohamed ben Youssef for dinner, a meeting that came to have considerable influence throughout history of the North African kingdom during the following years." (Stenner, 2014, p. 224) Although what had been discussed during the meeting remained mysterious because of the sudden death of the American president, Moroccans later declared that the American President had promised to support Morocco's independence once the Second World War was over. (Stenner, 2014, p. 224)

The first result of these transformations was the establishment of the first political party in Morocco bearing the name of independence on 10 December 1943. This political party, which gathered the best leaders of the nationalist movement under the leadership of Allal El Fassi, set as a priority objective the independence of Morocco. The second result was the submission of the independence manifesto to the French Resident on 11 January 1944 . The manifesto was signed by 66 nationalists who refused the reforms and demanded that the French protectorate grant Morocco full independence. The manifesto focused on four main demands which Bahij summarized as follows: "an independent Morocco under Sultan Mohammed V, that: Sultan Mohammed V himself should negotiate independence, that: Morocco should sign the Atlantic Charter and take part in the peace conference and that: the Sultan should establish a democratic government." (2013, p. 103)

The reaction of the French authorities was very violent. They launched a campaign of arrests and executions against the signatories of the manifesto. They were also furious with the Sultan, who expressed sympathy with the nationalists and their call for the independence of Morocco: "The Sultan, during a visit by a senior French diplomat, was given to understand that De Gaulle considered his evident sympathy for the nationalist cause to be evidence of disloyalty and ingratitude." (Joffé, 1985, p. 303) Therefore, it became clear that the French authorities wouldn't respond to any demand related to the independence of Morocco, which was an indication that the nationalist movement would resort to the armed struggle.

\section{Conclusion}

The establishment of the nationalist movement in Morocco was the result of many contributing factors, the most important of which was the promulgation of the Berber Dahir on 16 May, 1930. It is argued that the issuance of the Berber Dahir, which aimed to divide the Moroccan people into Arabs and Berbers, set off the first spark of protest against the French, thus, encouraged the nationalists to organize into what was later called the Moroccan nationalist movement.

The means of work that the movement adopted in its anti-colonial resistance were entirely peaceful. For instance, to preserve Morocco's cultural identity, which the French sought to obliterate through their racist educational system, the movement established national schools to teach young Moroccans Arabic, Moroccan history and the religion of Islam. The movement also used the press and media to communicate their nationalist ideas and publicize their demands. And to create a political representation for Moroccans to demand reforms in the face of French and Spanish colonialism, the movement established several parties, the most significant of which was the Istiqlal party.

This political resistance continued to demand reforms and equality with the citizens of the two colonial states residing in Morocco. However, the rejection of these demands by the colonial authorities made it clear that real reforms would not be achieved unless Morocco gained its independence. Therefore, the nationalists took advantage of the circumstances and events that accompanied the Second World War to call for Morocco's full independence. 


\section{References}

[1] [1] 'Azūz Ḥakīm, M. (1980). Ziyāra al-Amīr Šakīb Arslān li-I-Mag̉ib. Tetuán: s.n.

[2] [2] Ait Mous, F. (2013). The Moroccan nationalist movement: from local to nationalnetworks. The Journal of North African Studies, 18(5), 737-752.

[3] [3] Bahij, A. A. (2013). The socio-economic legacy of French colonialism in Morocco: The lasting impact of the French protectorate on Morrocan trade, agricultureand education. Doctoral dissertation, University of Bradford.

[4] [4] Bekraoui, M. (2003). Les étudiants marocains en France à l'époque du protectorat, 1927-1939'. Présences et images franco-marocaines au temps du protectorat, Paris: L'Harmattan.

[5] [5] Cleveland, W. L. (1985). Islam against the West: Shakib Arslan and the Campaign forlslamic Nationalism. Austin: University of Texas Press.

[6] [6] Cline, W. B. (1947). Nationalism in Morocco. The Middle East Journal, 18-28.

[7] [7] Damis, J. (1970). Developments in Morocco under the French protectorate, 19251943. The Middle East Journal, 74-86.

[8] [8] De Poli, B. (2016). The Nationalist Movement in Morocco and the Struggle for Independence between Civil Protest and Religious Propaganda (1930-1956). Università Ca' Foscari Venezia, Italia.

[9] [9] González González, I. (2015). The political instrumentalisation of an educationalmodel in a colonial context: Spanish-Arab schools in Spanish Morocco (1912-1956). The Journal of North African Studies, 20(2), 265-283.

[10] [10] Halstead, J. P. (1967). Rebirth of a Nation; the Origins and Rise of MoroccanNationalism, 1912-1944. Cambridge, Mass: Distributed for the Center for MiddleEastern Studies of Harvard University by Harvard University Press.

[11] [11] Joffé, E. G. H. (1985). The Moroccan nationalist movement: Istiqlal, the Sultan, and the country. Journal of African History, $289-307$.

[12] [12] Kenneth, B. (1972). The impact of the Dahir Berbère in Salé. Gellner-Micaud, Arabs\&Berbers, 201-215.

[13] [13] Lawrence, A. (2012). Rethinking Moroccan Nationalism, 1930-44. The Journal of North African Studies, 17(3), 475-490.

[14] [14] Montagne, R. (1937). La crise nationaliste au maroc. Politique étrangère, 2(6), 535-562.

[15] [15] Pennel, C.R. (2003). Morocco from Empire to Independence. Oxford: OneworldPublications.

[16] [16] Rachik, H., Laroui, A., \& Belal, Y. (2007). Nation, nationalisme et citoyenneté.Fondation Abderrahim Bouabid.

[17] [17] Séhimi, M. (1989). Révolution française et mouvement national marocain. Revue des mondes musulmans et de la Méditerranée, 52(1), 218-228. Ithaca and London: Cornell University Press.

[18] [18] Stenner, D. (2012). Networking for independence: the Moroccan nationalist movement and its global campaign against French colonialism. The Journal of North African Studies, 17(4), 573-594.

[19] [19] Stenner, D. (2014). Did Amrika promise Morocco's independence? The nationalist movement, the Sultan, and the making of the 'Roosevelt Myth'. The Journal of North African Studies, 19(4), 524-539.

[20] [20] Stenner, D. (2016). Centring the periphery: northern Morocco as a hub of transnational anticolonial activism, 1930-43. Journal of Global History, 11(3), 430.

[21] [21] Stenner, D. (2019). Globalizing Morocco: Transnational Activism and the Postcolonial State. Stanford, California: Stanford University Press.

[22] [22] Suliman, H. S. (1987). The nationalist movements in the Maghrib: a comparative approach. Nordiska Afrikainstitutet.

[23] [23] Tayebi, H. (2013). Print journalism in Morocco: From the pre-colonial period to the present day. Mediterranean Journal of Social Sciences, 4(6), 497.

[24] [24] Wyrtzen, J. D. (2009). Constructing Morocco: the colonial struggle to define the nation 1912-1956. Doctoral dissertation, Georgetown University.

[25] [25] Wyrtzen, J. (2011). Colonial state-building and the negotiation of Arab and Berber identity in protectorate Morocco. International Journal of Middle East Studies, 227- 249.

[26] [26] Wyrtzen, J. (2015). Making Morocco: colonial intervention and the politics of identity. Ithaca, N.Y.: Cornell University Press. 